\title{
Segmentation of the Inhabitants of Ljubljana with Regard to Environmental Issues
}

\author{
Segmentacija stanovnika Ljubljane s obzirom na njihov \\ odnos prema okolišu
}

With their lifestyles, characterised by ever-increasing material needs and anthropocentric worldview, humans are adversely affecting the environment and radically transforming it. Since their activities are significantly degrading the environment, their mentality, awareness, and behaviour are critical factors influencing the ways in which environmental burdens are generated and alleviated. Although it seems that people living in a particular environment have similar lifestyles, they are not a homogenous group with regard to their level of environmental awareness and engaging in environmentally friendly behaviour. The respondents were grouped according to their characteristics, using the K-means method, with regard to the studied attitudes, norms, perceived behaviour control, and values as well as with regard to the intention and the behaviour itself. They were divided into five groups: 1) "in word only", encompassing nearly a third; 2) "active", including a fifth; 3) "thrifty", encompassing a fifth; 4) "passive", including nearly a fifth; and 5) "indifferent", encompassing a tenth of the respondents.

Key words: consumer segmentation, attitudes, norms, values, perceived behavioural control, environmental awareness, environmental behaviour
Životnim stilom koji karakteriziraju sve veće materijalne potrebe i antropocentrički svjetonazor ljudi štetno utječu na okoliš te ga radikalno transformiraju. Budući da njihove djelatnosti značajno degradiraju okoliš, njihov mentalitet, svijest i ponašanje ključni su čimbenici koji utječu na povećanje ili smanjenje pritiska na okolišs. Iako se doima da ljudi koji žive u određenoj sredini imaju sličan životni stil, oni nisu homogena skupina s obzirom na razinu ekološke svijesti i prihvatljivog ponašanja prema okolišu. Ispitanici su grupirani prema karakteristikama, primjenom klaster analize, s obzirom na ispitane stavove i norme, percipiranu kontrolu ponašanja i vrijednosti te namjeru i samo ponašanje. Raspoređeni su u pet skupina: 1) skupinu „deklarativnih”, koja obuhvaća gotovo trećinu ispitanika, 2) skupinu „aktivnih”, koja uključuje petinu 3) skupinu ,"štedljivih”, koja obuhvaća petinu, 4) skupinu „pasivnih”, koja uključuje skoro petinu i 5) skupinu „,ravnodušnih”, koja obuhvaća desetinu ispitanika.

Ključne riječi: segmentacija potrošača, stavovi, norme, vrijednosti, percipirana kontrola ponašanja, ekološka svijest, ponašanje prema okolišu 


\section{Introduction}

People and their attitude towards the environment are the core research objective of the presented paper. Although there is a prevailing perception that people in the past respected the environment and managed their living space sensibly and responsibly, current generations are not the first ones to cause environmental deterioration (Plut, 2014). Namely, humans have always been affecting the natural environment, their own living space, with their activities, actually ever since they became aware of their primacy in the environment. Through an increasing level of civilisation development, constant inventions that helped humans to perform their work more easily, more powerful tools and machines and the growing population, our interference in the environment was becoming stronger and stronger, while our material demands were increasing (Smrekar, 2011). Economic development, particularly industrialisation, triggered the process that is becoming increasingly obvious: our interference with the functioning of the natural environment is becoming deeper and more intensive (Smrekar, 2012). Nevertheless, the blame cannot only be placed on the level of economic and technological development that enables this, but primarily on the attitude of humans towards the environment and its functioning (Polajnar, 2008; Polajnar Horvat, 2012).

Although human environmental conscience and behaviour have been a subject of research since as early as the 1970s (Lehman and Geller, 2004; Ham, 2009), less than a decade after the beginning of wider public support for environmental protection, interest in them has increased remarkably in the last two decades. The negative effects of our way of life and consumption are more obvious than ever, while at the same time people are also much more aware of them (Polajnar Horvat, 2014). Environmental behaviour is influenced by many factors (Gifford and Nilsson, 2014). They can be defined as factors originating from within humans themselves, as well as from the narrower or wider social environment, affecting their behaviour (Kollmuss and Agyeman, 2002; Clark et. al., 2003). Namely, every person is an independent whole, living in a social environment that directs and more or less influences people's lives. Among various known theories for explanation of the environmental behaviour of humans (Bamberg and Schmidt, 2003) and their segmentation

\section{Uvod}

Ljudi i njihov odnos prema okolišu središnji su istraživački cilj ovog rada. Iako prevladava uvjerenje da su ljudi u prošlosti poštovali okoliš i njime upravljali razumno i odgovorno, današnje generacije nisu prve koje uzrokuju degradaciju okoliša (Plut, 2014). Naime ljudi svojim djelatnostima oduvijek utječu na prirodni okoliš, tj. svoj životni prostor - zapravo otkad su postali svjesni svoje dominantne uloge u okolišu. Porastom razine civilizacijskog razvoja, brojnim izumima koji su čovjeku olakšali rad, snažnijim alatima i strojevima i porastom stanovništva iskorištavanje okolišnih resursa postaje sve opsežnije, a materijalne potrebe sve veće (Smrekar, 2011). Gospodarski razvoj, osobito industrijalizacija, pokrenuo je proces koji postaje sve očitiji: naše intervencije u prirodni okoliš postaju sve dublje i intenzivnije (Smrekar, 2012). No krivnju ne možemo pripisati isključivo stupnju gospodarskog i tehnološkog razvoja koji to omogućuje, već prije svega odnosu ljudi prema okolišu i njegovu djelovanju (Polajnar, 2008; Polajnar Horvat, 2012).

Ekološka svijest i ponašanje ljudi prema okolišu predmet su znanstvenih istraživanja od sedamdesetih godina prošlog stoljeća (Lehman i Geller, 2004; Ham, 2009). Manje od desetljeća nakon početka šire javne potpore zaštiti okoliša znatno je porastao interes za znanstvena istraživanja usporedno sa sve očitijim rastom negativnih učinaka našeg načina života i potrošnje te porastom naše svijesti o tim problemima (Polajnar Horvat, 2014). Na ponašanje prema okolišu utječu mnogi čimbenici (Gifford i Nilsson, 2014). Oni mogu biti definirani kao čimbenici koji potječu od samih ljudi, ali i od užega ili širega društvenog okruženja (Kollmus i Agyeman, 2002; Clark i dr., 2003). Naime svaka je osoba samostalna cjelina koja živi u društvenom okruženju koje određuje i više ili manje utječe na ljudske živote. Među različitim poznatim teorijama koje objašnjavaju ponašanje ljudi prema okolišu (Bamberg i Schmidt, 2003) i njihovu segmentaciju (Fraj i Martinez, 2006) jedan od etabliranih koncepata jest kombinacija promišljenih odluka i kolektivnih interesa ili motiva koji potiču djelovanje pogodno za okoliš. 
(Fraj and Martinez, 2006), one of the established concepts is a mixture of reasoned choices and collective interests or motives behind environmental action.

On the one hand, theories or models that are used are based on the assumption that environmentally friendly behaviour-leading psychological factors reflect individual considerations. Among them, the Theory of Planned Behaviour (Ajzen, 1991) is one of the most well-established. The Theory of Planned Behaviour emphasizes perceived individual benefits, constraints and perceived social pressures in relation to behavioural choices (Abrahamse, 2007). According to the theory, the immediate antecedent to behaviour is the behavioural intention to perform it. This behavioural intention is an indication of an individual's readiness to perform a given behaviour. It is based on attitude toward the behavior, subjective norms, and perceived behavioral control, with each predictor weighted for its importance in relation to the behavior and population of interest (Ajzen, 1991). On the other hand, models are used that are based on the assumption that environmentally friendly behaviour-leading psychological factors reflect environmental considerations and pro-environmental intent (Steg and Nordlund, 2013). Among them, the more recent Value-Belief-Norm theory (Stern, 2000) is well established. The Value-Belief-Norm theory (Stern 2000) presents a causal chain of variables, going from basic, general values and beliefs to behaviour-specific beliefs and norms to behaviour. It proposes that environmentally relevant behaviour emanates from the basic, general values people hold (Abrahamse, 2007). Values are at the very beginning of the causal chain and are related to a person's beliefs; responsibility levels in turn result in the activation of feelings of moral obligation and personal norms, which are believed to be direct antecedents of environmentally significant behaviours (Abrahamse, 2007). Since human action frequently involves the so-called "commons dilemma" or "social dilemma" where human action is directed toward individualisation of one's own benefits and consequently collectivisation of damage, it is reasonable to study human behaviour from both aspects. Namely, hitherto conducted research in the field of environmental behaviour is often focused only on studying one of the aforementioned theoretical bases (Stern and Dietz, 1994; Schultz and Zelezny, 1999; Stern, 2000; Nordlund and Garvill, 2002; Ajzen and Klobas, 2013;
S jedne strane, primijenjene teorije ili modeli temelje se na pretpostavci da je primjeren odnos prema okolišu posljedica psiholoških čimbenika koji odražavaju pojedinačna promišljanja. Među njima je teorija planiranog ponašanja (Ajzen, 1991) jedna od najviše objašnjavanih i najraširenijih. Ona ističe predviđanje individualne koristi, ograničenja i pretpostavljene društvene pritiske u odnosu na izbor ponašanja (Abrahamse, 2007). Prema toj teoriji, ponašanju neposredno prethodi namjera da se ono ostvari. Ta namjera indikacija je pripremljenosti pojedinca da ostvari to ponašanje. Ona se temelji na stavu o ponašanju, subjektivnim normama i percipiranoj kontroli ponašanja, pri čemu je svaka nezavisna varijabla ponderirana $u$ odnosu na ponašanje $i$ istraživanu populaciju (Ajzen, 1991). S druge se strane upotrebljavaju modeli koji se temelje na pretpostavci da je primjeren odnos prema okolišu posljedica psiholoških čimbenika koji odražavaju brigu za okoliš i namjere pogodne za okoliš (Steg i Nordlund, 2013). Među njima dobro je utvrđena teorija vrijednosti, uvjerenja i normi (Stern, 2000). Teorija vrijednosti, uvjerenja i normi (Value-belief-norm theory) (Stern, 2000) predstavlja slučajan niz varijabli - od osnovnih, općih vrijednosti i uvjerenja preko uvjerenja i normi specifičnih za određeno ponašanje do konkretnog ponašanja. Prema toj teoriji, ponašanje relevantno za okoliš izvire iz temeljnih, općeprihvaćenih vrijednosti (Abrahamse, 2007). $\mathrm{Na}$ samom su početku slučajnog niza vrijednosti povezane s uvjerenjima određene osobe, dok razine odgovornosti dovode do aktivacije osjećaja moralne obaveze, osobnih normi, za koje se vjeruje da izravno prethode okolišno relevantnom ponašanju (Abrahamse, 2007). Budući da ljudsko djelovanje često uključuje takozvanu „dilemu zajedničkih dobara” ili „socijalnu dilemu”, kod koje je ljudsko djelovanje usmjereno individualizaciji koristi pojedinca i stoga kolektivizaciji štete, opravdano je proučavati ljudsko ponašanje $s$ oba aspekta. Naime dosad provedena istraživanja na području ponašanja prema okolišu često se usredotočuju na proučavanje jedne od navedenih teorijskih osnova (Stern i Dietz, 1994; Schultz i Zelezny, 1999; Stern, 2000; Nordlund i Garvill, 2002; Ajzen i Klobas, 2013; Ajzen, 2015),
Segmentation of the Inhabitants of Ljubljana with Regard to Environmental Issues

Segmentacija stanovnika

Ljubljane s obzirom na njihov odnos prema okolišu 
GEOGRAFSKI

GLASNIK

78/1,25-44 (2016.)
Ajzen, 2015), while studying the interlacement of factors within both of them has rarely been attempted so far (Conner and Armitage, 1998; Harland, Staats and Wilke, 1999; Bamberg and Schmidt, 2003; Kaiser, 2006). In this study we focused on the extension of the Theory of Planned Behaviour with moral and normative dimensions of behaviour, namely the inclusion of personal norms, values and beliefs. Many modern authors (Stern et al., 1999; Schultz and Zelezny 2003; Heath and Gifford 2002; Bamberg and Schmidt, 2003; Kaiser, 2006) do confirm in their research the belief that the moral and normative dimension in the field of environmentally-friendly behaviors has great importance, to which the Theory of Planned Behavior does not devote sufficient attention.

Although the contemporary way of life in the developed world is not very diverse, the people, as far as the level of their environmental awareness and engaging in environment-friendly behaviour are concerned, are not a homogenous group as could easily be recognised and described (Gilg et. al., 2005; D'Souza et al., 2006; Culiberg and Rojšek, 2007). Therefore, in order properly to place and successfully implement social influence methods, which are used to develop environmental awareness and steer people's behaviour towards sustainability, it is of key importance to divide people into more precisely defined groups. In that way, the mentioned methods can be maximally adapted to every specific group and efficiency can be improved.

Furthermore, the studies are variously focused: some categorise people according to their general environmental behaviour (Ginsberg and Bloom, 2004), while many studies also exist that categorise them according to specific behaviour, for example, focusing on their consumption (Gilg et al., 2005; Bonini and Oppenheim, 2008; Ham, 2009). The purpose of this paper is to ascertain to what extent people differ in terms of environmental awareness and engaging in environmental behaviour, and whether they can be aggregated in groups that include individuals with similar behavioural characteristics while differing from other groups to the greatest extent possible. Only in this way can formed groups help in understanding people's environmental behaviour and designing adequate intervention strategies. dok se rijetko pokušavalo proučavati isprepletenost čimbenika unutar njih (Conner i Armitage, 1998; Harland, Staats i Wilke, 1999; Bamberg i Schmidt, 2003; Kaiser, 2006). U središtu ovoga istraživanja jest proširenje teorije planiranog ponašanja moralnim i normativnim dimenzijama ponašanja uključivanjem normi, vrijednosti i uvjerenja. Mnogi suvremeni autori (Stern i dr., 1999; Heath i Gifford, 2002; Bamberg i Schmidt, 2003; Schultz i Zelezny 2003; Kaiser, 2006) u svojim istraživanjima potvrđuju uvjerenje da su moralna i normativna dimenzija kod primjerenog odnosa prema okolišu od velikog značenja, čemu teorija planiranog ponašanja ne pridaje dovoljno pozornosti.

Iako suvremeni način života u razvijenom svijetu nije vrlo raznolik, ljudi se, barem u pogledu razine ekološke svijesti i primjerenog odnosa prema okolišu, ne mogu smatrati homogenom skupinom koju bi bilo lako prepoznati i opisati (Gilg i dr., 2005; D‘Souza i dr., 2006; Culiberg i Rojšek, 2007). Dakle, kako bismo primjereno smjestili i uspješno primijenili metode koje se upotrebljavaju za razvoj ekološke svijesti i usmjerivanje ponašanja prema održivosti, ključno je da ljudi budu razvrstani u točnije definirane skupine. Naime na taj način možemo navedene metode maksimalno prilagoditi svakoj specifičnoj skupini i tako poboljšati učinkovitost.

Štoviše, istraživanja su različito fokusirana: neka kategoriziraju ljude po njihovu općem ponašanju prema okolišu (Ginsberg i Bloom, 2004), dok postoje i mnoga istraživanja koja ih kategoriziraju po specifičnom ponašanju, primjerice potrošnji (Gilg i dr., 2005; Bonini i Oppenheim, 2008; Ham, 2009). Svrha je ovog rada utvrditi u kojoj se mjeri ljudi razlikuju u smislu ekološke svijesti i primjerenog odnosa prema okolišu i mogu li se grupirati u skupine koje uključuju pojedince sa sličnim karakteristikama u ponašanju razlikujući se pritom što je više moguće od ostalih skupina. Jedino tako formirane skupine mogu pripomoći razumijevanju ponašanja ljudi prema okolišu i oblikovanju primjerenih intervencijskih strategija. 
Method

408 individuals participated in the study in which the method of personal interviews was used.The study was carried out within the City Municipality of Ljubljana (CML) from $11^{\text {th }}$ of March to $5^{\text {th }}$ of May 2010, among permanent residents over 15 years of age. Stratified probability sampling was used, mostly in order to be able to take into account additional characteristics related to the studied phenomenon. It was ensured that the sample structure maximally corresponded to the structure of the population (demographic data for CML) in the study area; therefore, the selected demographic characteristics in creating the sample, i.e. age, sex and level of education, based on data obtained from the Statistical Office of the Republic of Slovenia, were followed.

The sample is rather equally divided between females (55.4\%) and males (44.6\%); $15.7 \%$ of the respondents are between 15 and 24 years of age, slightly over a third (35.0\%) are between 25 and 44 years of age, and $34.3 \%$ are between the age of 45 and 64 . Three out of twenty (15.0\%) of the respondents are over 65 years of age. Most of the respondents (51.0\%) have completed secondary education, $29.7 \%$ have completed higher or university education, $12.7 \%$ have completed vocational education and $6.6 \%$ have completed primary education or less. According to its sex and age structure, the sample complies with the criterion of sample representativeness at the level of CML. However, there are major discrepancies with regard to educational structure of the population, to which particular attention was paid when analysing the results.

As regards the content, various theoretical and practical foundations (the Ajzen's Theory of Planned Behaviour (Ajzen, 1991) and the Value-Belief-Norm Theory (Stern, 2000)) were taken into consideration in formulating questions. Values were measured using 10 so-called "quality of life indicators", which were determined on the basis of the Schwartz Values Scale (1992) and following previous research on the impact of values on environmental behavior (De Groot and Steg, 2007; Steg et al., 2012). Participants in the study were asked (on the five point Likert scale) how important they find the quality of life indicators (equality, justice, peace, power and influence, ambition, wealth, reputation and fame, comfort and enjoyment, joy of life,
Metoda

U istraživanju je upotrijebljena metoda ankete, a sudjelovalo je 408 ispitanika. Istraživanje je provedeno u gradskoj općini Ljubljana (GOL) od 11. ožujka do 5. svibnja 2010. među stalnim stanovništvom starijim od petnaest godina. Upotrijebljen je stratificirani slučajni uzorak, ponajviše kako bi se mogle uzeti u obzir dodatne karakteristike vezane uz proučavanu pojavu. Vodilo se računa da demografska struktura uzorka maksimalno odgovara strukturi stanovništva (demografski podaci za GOL); stoga su izabrane demografske karakteristike, tj. dob, spol i razina obrazovanja, koje su se temeljile na podacima dobivenima od Statističkog ureda Republike Slovenije.

U uzorku su relativno ravnomjerno zastupljene žene (55,4 \%) i muškarci (44,6 \%); 15,7 \% ispitanika u dobnoj je skupini 15 - 24 godine, trećina ispitanika (35,0 \%) nalazi se u dobnoj skupini 25 - 44 godine, a 34,3 \% spada u dobnu skupinu 45 64 godine. Troje od dvadeset (15,0 \%) ispitanika starije je od 65 godina. Većina ispitanika (51,0\%) ima završeno srednjoškolsko obrazovanje, 29,7 \% visoko ili fakultetsko obrazovanje, 12,7 \% strukovno obrazovanje, a 6,6 \% osnovno obrazovanje ili manje. Po spolnoj i dobnoj strukturi uzorak odgovara mjerilima reprezentativnosti uzorka na razini GOL-a. No postoje znatnija odstupanja u odnosu na obrazovnu strukturu stanovništva, čemu je kod analize rezultata posvećena posebna pozornost.

U pogledu sadržaja, kod formuliranja pitanja u obzir su uzete razne teorijske i praktične osnove - Ajzenova teorija planiranog ponašanja (Ajzen, 1991) te teorija vrijednosti, uvjerenja i normi (Stern, 2000). Vrijednosti su se mjerile uz pomoć takozvanih indikatora kvalitete života, koji su bili određeni na temelju Schwartzove ljestvice vrijednosti (1992.) nakon istraživanja utjecaja vrijednosti na ponašanje prema okolišu (De Groot i Steg, 2007; Steg i dr., 2012). Ispitanicima u istraživanju bilo je postavljeno pitanje (na Likertovoj ljestvici od pet stupnjeva) koliko važnim smatraju indikatore kvalitete života (jednakost, pravednost, mir, moć i utjecaj, ambiciju, bogatstvo, ugled i slavu, udob-
Segmentation of the Inhabitants of Ljubljana with Regard to Environmental Issues

Segmentacija stanovnika

Ljubljane s obzirom na njihov odnos prema okolišu 
GEOGRAFSKI

GLASNIK

78/1,25-44 (2016.) harmony with nature, protecting the environment) as their guiding principles in life. The principal component analysis was used to search for the common components of the quality of life indicators. Four main components were discarded, namely biospheric, altruistic, egoistic and hedonic values. Attitudes were measured with five items, which were composed of three sub-categories, ascription of responsibility, awareness of consequences and attitude on advisability of environmental protection, using the five-point Likert scale. Awareness of consequences was measured with two items "the amount of pumped water in the world is approaching the upper limits of available resources, which poses a major social problem" and "by saving water one can contribute to the conservation of valuable water resources". Ascription of responsibility was measured with two items "I feel responsible for the growing problems relating to water scarcity afflicting the world" and "I feel resposible for the excessive depletion of water resources for human needs". Attitude on advisability of environmental protection was measured with one item "we should conserve water in the households". Subjective norms were measured with two items "members of my family and friends think it is necessary to conserve water in households" and "I fully support the opinion of my family and friends on the use of water in households". Personal norms were measured with three items "I feel guilty when I use a lot of water" and "I feel morally obliged to reduce my water use, regardless of what other people do" and "I would consider myself a better person if I used less water". Perceived behavioral controls were measured with three items "I know how I can save water", "reducing my water use depends on me personally" and "I can reduce my energy use quite easily". Intention was measured with two items "I am willing to conserve water in the next six months" and "I will conserve water in the next six months". The reliability of constructs developed by the studied variables was measured by Cronbach's alpha (Cronbach, 1951). Actual behavior was measured by five constructs, the first three constructs measured the behaviour regarding conserving water, for example "how often do you leave a tap open while you brush your teeth?", the fourth one measured the willingness to participate in the Healthy Drinking Water Foundation to conserve water with a monthly contribution of 2 eur, the fifth one measured the willingness to participate in the environmentally active nost i uživanje, životnu radost, sklad s prirodom i očuvanje okoliša) kao temeljna načela života. Analiza glavnih komponenti bila je upotrijebljena za traženje zajedničkih komponenti indikatora kvalitete života. Utvrđene su četiri glavne komponente: biosferske, altruističke, egoistične i hedonističke vrijednosti. Stavovi su se mjerili s pet tvrdnji koje se sastoje od tri potkategorije: pripisivanje odgovornosti, svjesnost o posljedicama i odnos prema preporučljivom očuvanju okoliša na petostupanjskoj Likertovoj ljestvici. Svjesnost o posljedicama bila je ispitana dvjema tvrdnjama: „Količina potrošene vode u svijetu približava se gornjim granicama raspoloživih resursa, što uzrokuje društveni problem" $i$ „Štednjom vode možemo pridonijeti očuvanju dragocjenih vodnih resursa." Pripisivanje odgovornosti bilo je ispitano dvjema tvrdnjama: „Osjećam se odgovornim za porast problema vezanih uz nedostatak vode koji pogađa svijet” i „Osjećam se odgovornim za prekomjerno iscrpljivanje vodnih resursa za ljudske potrebe." Odnos prema preporučljivom očuvanju okoliša bio je ispitan tvrdnjom: „Trebali bismo štedjeti vodu u kućanstvima." Subjektivne norme bile su mjerene dvjema tvrdnjama: „Clanovi moje obitelji i moji prijatelji misle da je potrebno štedjeti vodu u kućanstvima” $i$ „U potpunosti podupirem mišljenje svoje obitelji i prijatelja u pogledu potrošnje vode u kućanstvima." Osobne norme bile su ispitane trima tvrdnjama: „Osjećam se krivim kada potrošim puno vode”, „Osjećam se moralno obveznim smanjiti svoju potrošnju vode bez obzira na to što čine drugi ljudi” $i$ „Smatrao bih se boljom osobom ako bih potrošio manje vode." Percepcija kontrole ponašanja bila je ispitana trima tvrdnjama: „Znam kako štedjeti vodu”, „Smanjenje moje potrošnje vode ovisi o meni osobno” i „Prilično lako mogu smanjiti svoju potrošnju energije." Namjera se ispitivala dvjema tvrdnjama: „Spreman sam štedjeti vodu u sljedećih šest mjeseci” i „Sljedećih šest mjeseci štedjet ću vodu." Pouzdanost pitanja oblikovanih pomoću upotrijebljenih varijabli ispitana je Cronbachovim alfa-koeficijentom (Cronbach, 1951). Stvarno ponašanje ispitano je s pet pitanja; prva tri ispitivala su ponašanje vezano uz štednju vode, primjerice: „Koliko često ostavljate odvrnutu slavinu dok perete zube?”, četvrtim se pitanjem ispitivala spremnost za sudjelovanje u Fondaciji za zdravu pitku vodu s mjesečnim doprinosom od dva 
group, Ecological. The five constructs were than merged into one variable called Behaviour.

Respondents were divided into groups according to their characteristics, using the K-means method (Tab. 1). The similarity principle was used in such a way that individuals who were most similar to each other with regard to the studied factors were integrated into a certain group, while the groups themselves differed as much as possible with regard to the aforementioned factors. The number of groups was determined by the cluster-randomized trial and error process. Every group was composed of respondents who - with regard to the studied attitudes, norms (personal and subjective), perceived behaviour control, values, as well as with regard to the intention and the behaviour itself - are similar to each other as much as possible or are more similar to each other than to the respondents from other groups. In order to find out what kind of individuals we were dealing with within individual groups, the resulting groups were analysed with regard to the studied social factors, motivation for environment-friendly behaviour and with regard to the behaviour itself.

\section{Results}

According to the results of the analysis, five groups can be distinguished (Tab. 2). Based on the answers provided by the respondents, these groups differ in statistical significance, while they are substantively relevant and important at the same time. The first group, named "active", encompasses a fifth (20.7\%) of the respondents. The same percentage $(20.7 \%)$ of the respondents fall into the second group, named "thrifty". The third group, named "in word only", includes slightly less than a third (28.0\%) of the respondents, the group named "passive" encompasses almost a fifth (19.2\%) of the respondents, while slightly more than a tenth $(11.4 \%)$ of the respondents fall into the fifth group, named "indifferent".

The "active" group is characterised by the high level of environmental awareness, which is shown by attaching above-average importance to attitudes, subjective norms and perceived behaviour, while importance assigned to personal norms, particularly, exceeds the average. Therefore, these respondents mostly "agree" or "strongly agree" with the studied attitudes. They are eura, a petim spremnost za sudjelovanje u ekološki aktivnoj skupini Ekologičen. Odgovori na pet pitanja bili su zatim spojeni u jednu varijablu nazvanu „ponašanje”.

Ispitanici su bili raspoređeni u pet skupina prema karakteristikama pomoću klaster analize (tab. 1). Načelo sličnosti bilo je upotrijebljeno na način da su pojedinci sa sličnim karakteristikama grupirani u istu skupinu, dok su se skupine međusobno razlikovale što je više bilo moguće s obzirom na navedene faktore. Broj skupina bio je određen metodom pokušaja i pogrešaka u slučajnom grupiranju klastera. Svaka se skupina sastojala od ispitanika koji su - u odnosu na istraživane stavove, norme (osobne i subjektivne), percipiranu kontrolu ponašanja i vrijednosti, kao i na namjeru i samo ponašanje - međusobno što sličniji ili sličniji jedan drugome nego ispitanicima iz drugih skupina. S ciljem utvrđivanja karakteristika pojedinaca unutar pojedinih skupina, te su skupine bile analizirane u odnosu na istraživane društvene čimbenike i motiviranost za primjeren odnos prema okolišu, kao i prema samom ponašanju.

\section{Rezultati}

Rezultati analize pokazuju da možemo identificirati pet skupina ispitanika (tab. 2). Na osnovi odgovora koje su dali ispitanici te se skupine međusobno statistički značajno razlikuju, dok su sadržajno relevantne i značajne. Prva skupina, koju smo nazvali „aktivni”, obuhvaća petinu (20,7 \%) ispitanika. Isti postotak (20,7\%) ispitanika spada u drugu skupinu nazvanu „štedljivi”. Treća skupina, koju smo nazvali „deklarativni”, obuhvaća malo manje od trećine (28,0 \%) ispitanika, četvrta, „pasivni”, petinu (19,2\%) ispitanika, a u petu skupinu, nazvanu „ravnodušni”, spada malo više od desetine $(11,4 \%)$ ispitanika.

Skupinu „aktivnih” karakterizira visoka razina ekološke svijesti koja se odražava u pripisivanju iznadprosječnog značenja stavovima, subjektivnim normama i percipiranom ponašanju, dok pripisivanje značenja osobnim normama znatno prelazi prosjek. Stoga se ti ispitanici „slažu” ili „izrazito slažu” s istraživanim stavovima. Usto ih karakterizira i pripisivanje vrlo velike važnosti
K. Polajnar Horvat

Segmentation of the Inhabitants of Ljubljana with Regard to

Environmental Issues

Segmentacija stanovnika

Ljubljane s obzirom na njihov odnos prema okolišu 
HRVATSKI

GEOGRAFSKI

GLASNIK

78/1,25-44 (2016.)

Tab. 1 Statistical reliability of K-means Method

Tab. 1. Statistička pouzdanost klaster analize (K-means)

\begin{tabular}{|c|c|c|c|c|c|c|}
\hline \multirow[b]{2}{*}{ Variable / Varijabla } & \multicolumn{2}{|c|}{ Cluster / Klaster } & \multicolumn{2}{|c|}{ Error / Pogreška } & \multirow[b]{2}{*}{$\mathrm{F}$} & \multirow[b]{2}{*}{ Sig. } \\
\hline & $\begin{array}{c}\text { Mean } \\
\text { Square / } \\
\text { Srednja } \\
\text { kvadratna } \\
\text { vrijednost }\end{array}$ & df & \begin{tabular}{|c|} 
Mean \\
Square / \\
Srednja \\
kvadratna \\
vrijednost \\
\end{tabular} & df & & \\
\hline Attitudes / Stavovi & 31,79 & 4 & 0,26 & 381 & 123,78 & 0,000 \\
\hline Personal norms / Osobne norme & 59,84 & 4 & 0,34 & 381 & 175,16 & 0,000 \\
\hline Subjective norms / Subjektivne norme & 26,22 & 4 & 0,37 & 381 & 70,82 & 0,000 \\
\hline $\begin{array}{l}\text { Perceived behavioral control / Percipirana } \\
\text { kontrola ponašanja }\end{array}$ & 45,27 & 4 & 0,40 & 381 & 113,41 & 0,000 \\
\hline Altruistic values / Altruističke vrijednosti & 4,85 & 4 & 0,24 & 381 & 20,10 & 0,000 \\
\hline Biospheric values / Biosferske vrijednosti & 26,72 & 4 & 0,34 & 381 & 79,73 & 0,000 \\
\hline Hedonistic values / Hedonističke vrijednosti & 8,88 & 4 & 0,40 & 381 & 22,10 & 0,000 \\
\hline Egoistic values / Egoistične vrijednosti & 14,49 & 4 & 0,53 & 381 & 27,61 & 0,000 \\
\hline Intention / Namjera & 39,76 & 4 & 0,46 & 381 & 86,83 & 0,000 \\
\hline Behaviour / Ponašanje & 30,99 & 4 & 0,55 & 381 & 55,96 & 0,000 \\
\hline
\end{tabular}

also characterised by assigning very high importance to biospheric values, which is not surprising due to the fact that they are reflected in concern for and protection of the environment. The so-called "environmental body" of the studied area also attaches above-average importance to altruistic values, while at the same time it is characterised by attaching below-average importance to hedonistic values, and particularly to egoistic values that it considers distinctly unimportant. In a way, the group is characterised by assigning high importance to biospherical values and distinctly high importance to personal norms, which reveals their high sense of guilt when they fail to care for the environment, a very high sense of personal moral responsibility for environmental activity and internal positive feelings when they engage in environment-friendly behaviour.

In the so-called "thrifty" group, the level of agreement with the studied variables is moderate, generally slightly below mean values, or below the average of answers given by the entire studied group. Their position regarding the studied attitudes is mostly neutral biosferskim vrijednostima, što ne iznenađuje jer se odražavaju u zabrinutosti za okoliš i želji za njegovim očuvanjem. Takozvano „ekološko tijelo" istraživanog područja pripisuje iznadprosječnu važnost i altruističkim vrijednostima te istovremeno ispodprosječnu važnost hedonističkim vrijednostima i osobito egoističnim vrijednostima, koje smatra izrazito nebitnima. Tu skupinu donekle karakterizira pripisivanje velike važnosti biosferskim vrijednostima i izrazito velike važnosti osobnim normama, iz čega proizlaze njihov jaki osjećaj krivnje kada se ne uspijevaju brinuti za okoliš, vrlo jaki osjećaj osobne moralne odgovornosti za ekološku aktivnost i pozitivni osjećaji kada se primjereno ponašaju prema okolišu.

U takozvanoj skupini „štedljivih” razina je slaganja s proučenim varijablama umjerena, općenito malo ispod prosječnih vrijednosti ili ispod prosjeka odgovora svih ispitanika u istraživanju. Njihovo je stajalište prema proučenim tvrdnjama većinom neutralno ili umjereno pozitivno, što 
or moderately positive, which means that they "agree" or "neither agree nor disagree with them". They are most critical in rating subjective norms, the perceived behaviour control and personal norms. Thus, they assign below-average importance to the opinions of their friends or relatives on the importance of active environmental engagement and the support itself expressed by their opinions. Furthermore, they feel less capable of active environmental engagement and at the same time they believe there is no sense in engaging in such activities if others do not act in such a way. In cases of non-environmental behaviour, their sense of guilt and moral responsibility is not so high, while they are also not so strongly guided by internal feelings when it comes to actions related to the environment. The "thrifty" respondents attach the highest, above-average importance to egoistic values, while interestingly, they assign below-average importance to hedonistic values. The group considers wealth and money as well as power, fame and influence to be more important than the notion that the ultimate purpose of a person's life is pleasure. They assign below-average importance to altruistic values, while they are more critical in rating biospheric values.

The "in word only" group is characterised by valuing perceived behavioural control, attitudes and subjective norms considerably above the average, while personal norms are valued somewhere around the average. Having predominantly answered by "I agree" or "I strongly agree", the "in word only" respondents mostly feel capable of active environment-friendly engagement and are at the same time convinced that they are well-informed about the ways of appropriate acting. They also predominantly express their inclination towards environment-friendly behaviour, seem to be aware of the consequences of inappropriate behaviour and seem to understand that, in principle, responsibility needs to be taken for inappropriate behaviour. They also assign very high importance to subjective norms, i.e. the individual's perceptions of normative expectations of significant others and willingness to take their opinions into account in their behaviour. On the other hand, interestingly, they consider personal norms to be much less important, which implies that their principle-based support is diminished by their own sense of guilt, their own sincere inner feeling about environment-friendly behaviour and their own morality. On average, the respondents also rate values by predominantly answering znači da se s njima "slažu” ili „niti slažu niti ne slažu”. Najkritičniji su kod ocjenjivanja subjektivnih normi, percipirane kontrole ponašanja i osobnih normi. Stoga pripisuju ispodprosječnu važnost mišljenju svojih prijatelja ili rođaka o važnosti aktivnog okolišno pogodnog djelovanja i samoj podršci izraženoj u tim mišljenjima. $\mathrm{Na}-$ dalje, osjećaju se manje sposobnima aktivno ekološki djelovati i istovremeno smatraju da nema smisla baviti se takvim aktivnostima ako tako ne djeluju i drugi. U primjerima okolišno neprihvatljivog ponašanja njihov osjećaj krivnje i moralne odgovornosti nije tako jak, a istodobno nisu toliko vođeni osjećajima kada je posrijedi djelovanje vezano uz okoliš. „Štedljivi” ispitanici pripisuju najveću, iznadprosječnu, važnost egoističnim vrijednostima te, zanimljivo, ispodprosječnu važnost hedonističkim vrijednostima. Skupina smatra bogatstvo i novac te moć, slavu i utjecaj važnijima od nazora da je cilj čovjekova života uživanje. Ispodprosječnu važnost pripisuju altruističkim vrijednostima, a kritičniji su kod ocjenjivanja biosferskih vrijednosti.

Skupinu „deklarativnih” karakterizira pripisivanje značajno iznadprosječne važnosti percipiranoj kontroli ponašanja, stavovima i subjektivnim normama, dok osobne norme svrstavaju blizu prosjeka. Ispitanici iz skupine „deklarativnih”, koji su većinom odgovorili „slažem se” ili „izrazito se slažem”, osjećaju se sposobnima aktivno okolišno primjereno djelovati, a istovremeno su uvjereni da su dobro informirani o načinima primjerenog djelovanja. Oni također pretežno izražavaju naklonost okolišno primjerenom ponašanju, svjesni su posljedica neprimjerenog ponašanja i razumiju da je u načelu potrebno preuzimati odgovornost za neprimjereno ponašanje. Također pripisuju vrlo veliku važnost osobnim normama, tj. percepciji pojedinaca o normativnim očekivanjima njihovih partnera i spremnost da njihovo mišljenje uzmu u obzir u svom ponašanju. S druge strane, zanimljivo, osobnim normama pripisuju znatno manju važnost, što pokazuje da njihovu načelnu podršku smanjuje njihov osjećaj krivnje, njihov iskreni osjećaj u pogledu ponašanja pogodnog za okoliš i njihov moral. Ispitanici u prosjeku ocjenjuju vrijednosti odgovorom „slažem se", bez znatnijih razlika među vrijednostima.
Segmentation of the Inhabitants of Ljubljana with Regard to Environmental Issues

Segmentacija stanovnika

Ljubljane s obzirom na njihov odnos prema okolišu 
GEOGRAFSKI

GLASNIK

78/1,25-44 (2016.)
"I agree", with no significant differences among the values. Thus, the respondents strongly support environmental protection and demonstrate a very high level of environmental awareness at the declarative level.

The "passive" respondents consider attitudes to be of average importance. At the declarative level, they are aware of the need for environment-friendly engagement and they express concern about the environment. They also attach relatively high importance - somewhere around the average - to personal norms, subjective norms and the perceived behavioural control. They agree that something has to be done for the benefit of the environment regardless the fact that others do not do it. To a certain point, they feel guilty and morally responsible when they fail to act in favour of the environment. As far as values are concerned, their rating of hedonistic values is above the average, which means that they assign rather high importance to their own enjoyment, while they consider egoistic values to be less important. They consider biospheric and altruistic values to be of average importance. Thus, the "passive" respondents can also be placed among the environmentally aware and the supporters of environmental protection at the declarative level.

The "indifferent" group is characterised by rating personal norms, attitudes, subjective norms and the perceived behavioural control distinctly below the average. They mostly disagree with the statements measuring the mentioned dimensions. They negatively rate the need for environment-friendly engagement, they see themselves as highly incapable of such behaviour, and they also believe they do not know how to act appropriately. They are unaware of the consequences of inappropriate environmental behaviour and they do not feel responsible for such consequences. They expressly disagree with feeling a sense of guilt for inappropriate environmental behaviour, they feel no moral responsibility whatsoever and have absolutely no bad conscience about that. As far as values are concerned, their rating of egoistic values is distinctly above the average, the highest among all studied groups. They rate hedonistic values above the average as well, while they expectedly rate altruistic, and particularly biospheric, values below the average. Respondents from this group believe that they cannot contribute much to preservation of the environment, and the level of their environmental awareness is very low as well.
Prema tome, snažno podupiru zaštitu okoliša i pokazuju visoku ekološku svijest na deklarativnoj razini.

„Pasivni” ispitanici pripisuju stavovima prosječnu važnost. Na deklarativnoj razini svjesni su potrebe primjerenog djelovanja prema okolišu i pokazuju brigu za okoliš. Također pripisuju relativno veliku važnost - približno oko prosjeka - osobnim normama, subjektivnim normama i percipiranoj kontroli ponašanja. Slažu se da treba učiniti ponešto korisno za okoliš iako drugi to ne čine. Osjećaju se donekle krivima i moralno odgovornima kada njihovo djelovanje nije primjereno za okoliš. Š to se vrijednosti tiče, njihova je ocjena hedonističke vrijednosti iznad prosjeka, što znači da pripisuju veliku važnost svojem uživanju, dok egoistične vrijednosti smatraju manje važnima. Biosferskim i altruističkim vrijednostima pripisuju prosječnu važnost. Stoga se „pasivni” ispitanici mogu svrstati između ekološki osviještenih i pristaša očuvanja okoliša na deklarativnoj razini.

Skupinu „ravnodušnih” karakterizira pripisivanje izrazito ispodprosječne važnosti osobnim normama, stavovima, objektivnim normama i zamijećenoj kontroli ponašanja. Uglavnom se ne slažu s tvrdnjama kojima se mjere spomenute dimenzije. Negativno ocjenjuju potrebu za primjerenim djelovanjem prema okolišu, smatraju se izrazito nesposobnima za takvo djelovanje i misle da ne poznaju primjerene načine djelovanja. Također nisu svjesni neprimjerenog ponašanja prema okolišu i ne osjećaju se krivima zbog posljedica takva ponašanja. Izrazito se ne slažu s osjećajem krivnje zbog neprimjerenog ponašanja prema okolišu, ne osjećaju nikakvu moralnu odgovornost i u vezi s tim uopće ih ne muči savjest. $U$ pogledu vrijednosti, egoističnim vrijednostima pripisuju izrazito iznadprosječnu važnost, najvišu među svim istraživanim skupinama. Hedonističke vrijednosti također ocjenjuju iznad prosjeka, dok očekivano pripisuju ispodprosječnu važnost altruističkim, a pogotovo biosferskim vrijednostima. Ispitanici iz ove skupine smatraju da ne mogu znatnije pridonijeti očuvanju okoliša, a razina njihove ekološke svijesti jako je niska. 
Tab. 2 Mean values and indexes of studied variables by extracted groups based on personal interviews Tab. 2. Prosječne vrijednosti i indeksi istraženih varijabli po identificiranim skupinama na osnovi anketa

\begin{tabular}{|c|c|c|c|c|c|c|c|}
\hline Variable / Varijabla & $\begin{array}{l}\text { Unit / } \\
\text { Jedinica }\end{array}$ & 1 & 2 & 3 & 4 & 5 & 6 \\
\hline \multirow{2}{*}{ Attitudes / Stavovi } & $\overline{\mathrm{x}}$ & 3.51 & 3.32 & 3.90 & 3.35 & 2.44 & 3.42 \\
\hline & Index & 102 & 97 & 114 & 98 & 71 & 100 \\
\hline \multirow{2}{*}{ Personal norms / Osobne norme } & $\overline{\mathrm{x}}$ & 4.17 & 3.37 & 3.82 & 3.44 & 2.39 & 3.56 \\
\hline & Index & 117 & 95 & 106 & 97 & 67 & 100 \\
\hline \multirow{2}{*}{ Subjective norms / Subjektivne norme } & $\overline{\mathrm{x}}$ & 3.95 & 3.49 & 4.22 & 3.75 & 2.74 & 3.75 \\
\hline & Index & 105 & 93 & 113 & 100 & 73 & 100 \\
\hline \multirow{2}{*}{$\begin{array}{l}\text { Perceived behavioral control / Percipirana } \\
\text { kontrola ponašanja }\end{array}$} & $\overline{\mathrm{x}}$ & 3.74 & 3.46 & 4.21 & 3.63 & 2.81 & 3.68 \\
\hline & Index & 102 & 94 & 115 & 99 & 76 & 100 \\
\hline \multirow{2}{*}{ Altruistic values / Altruističke vrijednosti } & $\overline{\mathrm{x}}$ & 4.78 & 4.63 & 4.71 & 4.53 & 4.13 & 4.6 \\
\hline & Index & 104 & 100 & 102 & 98 & 89 & 100 \\
\hline \multirow{2}{*}{ Biospheric values / Biosferske vrijednosti } & $\overline{\mathrm{x}}$ & 4.80 & 3.95 & 4.50 & 4.22 & 3.14 & 4.24 \\
\hline & Index & 114 & 94 & 105 & 99 & 74 & 100 \\
\hline \multirow{2}{*}{ Hedonistic values / Hedonističke vrijednosti } & $\overline{\mathrm{x}}$ & 3.87 & 3.90 & 4.51 & 4.41 & 4.42 & 4.22 \\
\hline & Index & 91 & 92 & 106 & 104 & 105 & 100 \\
\hline \multirow{2}{*}{ Egoistic values / Egoistične vrijednosti } & $\overline{\mathrm{x}}$ & 2.36 & 3.44 & 3.06 & 2.77 & 3.51 & 2.96 \\
\hline & Index & 79 & 114 & 102 & 93 & 119 & 100 \\
\hline \multirow{2}{*}{ Intention / Namjera } & $\overline{\mathrm{x}}$ & 4.59 & 3.72 & 4.31 & 2.91 & 2.90 & 3.82 \\
\hline & Index & 120 & 97 & 113 & 76 & 76 & 100 \\
\hline \multirow{2}{*}{ Behaviour / Ponašanje } & $\overline{\mathrm{x}}$ & 4.10 & 3.45 & 3.07 & 2.75 & 1.93 & 3.19 \\
\hline & Index & 129 & 108 & 96 & 86 & 61 & 100 \\
\hline
\end{tabular}

(1 - active / aktivni, 2- thrifty / štedljivi, 3-in word only / deklarativni, 4-passive / pasivni, 5-indifferent / ravnodušni, 6- total / ukupno)

Knowledge proved to be one of the decisive factors influencing actual engaging in environmental behaviour. The results show that average knowledge at the level of the entire population is rather poor. Knowledge of the "active" group is distinctly above the average, while knowledge of the "thrifty" group is of average level, which suggests that their knowledge is
K. Polajnar Horvat

Segmentation of the Inhabitants of Ljubljana with Regard to

Environmental Issues

Segmentacija stanovnika Ljubljane s obzirom na njihov odnos prema okolišu
Znanje se pokazalo kao jedan od odlučujućih čimbenika koji utječu na primjereno ponašanje prema okolišu. Rezultati pokazuju da je prosječno znanje na razini cjelokupne populacije relativno slabo. Znanje skupine „aktivnih” izrazito prelazi prosjek, dok je znanje skupine „štedljivih” prosječno, dakle relativno slabo, osobito u odnosu 
GEOGRAFSKI

GLASNIK

78/1, 25-44 (2016.) relatively poor, particularly as regards knowledge on daily quantities of used water and quantities of water required for specific activities. Namely, their answers differ from the true values by more than $60 \%$. Interestingly, compared to mean values of all respondents or to average values of all answers, knowledge of the "in word only" group is mostly above the average, while the "passive" and, even more so, "indifferent" groups are characterised by remarkably poor knowledge of the studied subject matter.

It was also studied what kind of intentions or motivations for environment-friendly behaviour and behaviour in general characterise each of the extracted groups or their members. According to the results, the highest level of intention for environment-friendly behaviour is demonstrated by the "active" group (index 120), followed by the "in word only" group, which shows markedly above-average willingness to engage in environment-friendly behaviour (index 113). The "thrifty" group (index 97) is slightly below the average, while the lowest level of willingness to engage in environment-friendly behaviour is shown by the "passive" and "indifferent" groups. Considering the behaviour variable, it can be concluded that the most rational behaviour characterises the "active" group (index 129), followed by the so called "thrifty" group (index 108). Average or slightly below-average behaviour characterises the "in word only" group (index 96). As suggested by its name, behaviour of the "passive" group is rather below the average (index 86), while behaviour of the "indifferent" group is distinctly below the average (index 61).

It was also studied to what extent are respondents in particular groups were willing to engage actively in environment-friendly behaviour, which was measured by their willingness to join the environmental group Ecological, financially to support environmental protection, which was measured by contributions to the Healthy Drinking Water Foundation, and actually participate actively by joining the Ecological group (Tab. 3). Slightly over two thirds (68.1\%) of all respondents were willing to offer financial support to the Foundation. Within the "active" group, all of the respondents expressed their willingness financially to support the Healthy Drinking Water Foundation in the monthly amount of EUR 0.5 (index 147). Willingness of the "in word only" group was also considerably above the average - na znanje o dnevnim količinama potrošene vode i količinama vode koja je potrebna za određene aktivnosti. Naime njihovi se odgovori za više od $60 \%$ razlikuju od točnih vrijednosti. Zanimljiva je činjenica da je u usporedbi s prosječnim vrijednostima svih ispitanika ili prosječnim vrijednostima svih odgovora znanje skupine "deklarativnih” iznad prosjeka, dok skupinu „pasivnih”, a još izrazitije „ravnodušnih”, karakterizira osobito slabo znanje o istraživanoj temi.

Također smo proučili kakve namjere ili motivacije za okolišno primjereno ponašanje i opće ponašanje karakteriziraju svaku od identificiranih skupina i njihove pripadnike. Prema rezultatima, najveću namjeru za okolišno primjereno ponašanje pokazuje skupina „aktivnih” (indeks 120). Slijedi skupina „deklarativnih”, koja pokazuje znatno iznadprosječnu spremnost za okolišno primjereno ponašanje (indeks 113). Malo ispod prosjeka nalazi se skupina „štedljivih” (indeks 97), dok najnižu razinu spremnosti za primjenu okolišno primjerenog ponašanja pokazuju skupine „pasivnih” i „ravnodušnih”. Kad pogledamo varijablu ponašanja, možemo zaključiti da najracionalnije ponašanje karakterizira skupinu „aktivnih” (indeks 129), koju slijedi skupina ,„̌tedljivih” (indeks 108). Prosječno ili malo ispodprosječno ponašanje karakterizira skupinu "deklarativnih” (indeks 96). Kako i upućuje ime skupine „pasivnih", ponašanje njenih članova prilično je ispod prosjeka (indeks 86), a skupina „ravnodušnih” izrazito je ispod prosjeka (indeks 61).

Također smo istražili spremnost ispitanika u pojedinim skupinama za aktivnu primjenu okolišno primjerenog ponašanja, što se mjerilo njihovom spremnošću da se pridruže ekološkoj skupini Ekologičen, na financijsku potporu očuvanja okoliša, što se mjerilo doprinosima Fondaciji za zdravu pitku vodu, i na stvarno aktivno sudjelovanje u obliku pristupanja skupini Ekologičen (tab. 3). Malo više od dvije trećine $(68,1 \%)$ svih ispitanika bilo je spremno financijski poduprijeti Fondaciju. U skupini „aktivnih” svi su ispitanici izrazili spremnost da financijski podrže Fondaciju za zdravu pitku vodu u mjesečnom iznosu od 0,5 eura (indeks 147). Spremnost skupine „deklarativnih" bila je također znatno iznad prosjeka 
nine out of ten group members (90.1\%) were in favour of financially supporting the Foundation. That was followed by the "passive" group, where the willingness was already considerably below the average, being only slightly above a half (55.2\%) of group members willing to support the Foundation. The lowest willingness characterises the so-called "thrifty" group where a half (51.3\%) of group members were in favour of support, and the "indifferent" group where slightly more than one out of ten (12.6\%) members expressed a positive attitude towards this idea. Further, we were curious about how many members of a particular group were willing to contribute EUR 2 or more per month for the Healthy Drinking Water Foundation. In this case, slightly less than one fifth (19.2\%) of all respondents were willing to contribute. The distinctly above-average willingness is characteristic of the "active" group where more than a third of group members (40.0\%) expressed their willingness. Rather surprisingly, they are followed by the "in word only" group where slightly over a fifth (24.3\%) of members expressed their willingness. Lower willingness characterises the "passive" group where the tenth (10.4\%) expressed a positive attitude towards financial support, while the lowest rates were recorded in the "thrifty" group with 5.0\% members and the "indifferent" group with less than one out of twenty $(4.5 \%)$ members in favour of financial support.

Contrary to a rather high percentage of those willing financially to support the Foundation, the share of respondents who were willing to join the real environmental group Ecological, with preservation and protection of the environment as its primary goal, and also to give their e-mail address, is below a fifth (18.2\%). Expectedly, the "active" group is the most eager in this respect, with slightly more than a half of its members (53.4\%) willing to join the group. They are followed by the "thrifty" group with slightly less than a fifth (18.0\%) of its members willing to join, while $10.2 \%$ of the "in word only" group members expressed their willingness to join. No members of the "passive" and "indifferent" groups were willing to join the Ecological group, which was somehow expected. In the end we wanted to find out the percentage of all respondents that actually joined the group. Only one in every 25 respondents (4.2\%) decided to do so; of those, the vast majority was from the "active" group, while one was from the "thrifty" group and one from the "in word only" group.
- devet desetina pripadnika skupine (90,1\%) bilo je za financijsku potporu Fondacije. Slijedila je skupina „pasivnih”, kod koje je spremnost bila već znatno ispod prosjeka, s malo više od polovine $(55,2 \%)$ pripadnika spremnih poduprijeti Fondaciju. Najniža spremnost karakterizira skupinu „štedljivih”, u kojoj je za potporu bila polovina $(51,3 \%)$ pripadnika, i skupinu „ravnodušnih”, u kojoj je malo više od desetine (12,6 \%) pripadnika izrazilo pozitivan stav prema toj ideji. Nadalje nas je zanimalo koliko je pripadnika pojedinih skupina spremno dati doprinos od dva eura mjesečno Fondaciji za zdravu pitku vodu. Malo manje od petine $(19,2 \%)$ svih ispitanika bilo je spremno to učiniti. Spremnost izrazito iznad prosjeka karakterizira skupinu „aktivnih”, u kojoj je više od trećine pripadnika (40,0 \%) izrazilo svoju spremnost. Prilično začuđujuće, slijedi skupina "deklarativnih", u kojoj je spremnost izrazilo malo više od petine (24,3 \%) pripadnika. Manja spremnost karakterizira skupinu „pasivnih”, u kojoj je desetina $(10,4 \%)$ pripadnika izrazila pozitivan stav prema financijskoj potpori, dok su najniže vrijednosti zabilježene u skupini, „štedljivih”, s 5,0 \% pripadnika, i skupini „ravnodušnih”, s manje od dvadesetine (4,5\%) pripadnika naklonjenih financijskoj potpori.

Za razliku od visokog udjela onih koji su spremni financijski podržati Fondaciju, udio je ispitanika koji su bili spremni uključiti se u pravu ekološku skupinu Ekologičen, čiji je primarni cilj očuvanje i zaštita okoliša, i dati svoju adresu elektroničke pošte, ispod petine (18,2 \%). Očekivano, skupina "aktivnih" bila je najmotiviranija u tom pogledu, s malo više od polovine pripadnika $(53,4 \%)$ spremnih pridružiti se skupini. Slijedila je skupina „štedljivih”, u kojoj je malo manje od petine $(18,0 \%)$ pripadnika bilo spremno pridružiti se, a u skupini „deklarativnih” 10,2 \% pripadnika izrazilo je spremnost na to. Skupini Ekologičen nije se želio pridružiti nijedan pripadnik skupina „pasivnih” i „ravnodušnih”, što je donekle bilo u skladu s očekivanjima. Na kraju smo željeli doznati koliki se udio ispitanika stvarno pridružio skupini. Samo je svaki 25. ispitanik (4,2 \%) odlučio to učiniti; od njih je velika većina bila iz skupine „aktivnih”, jedan je bilo iz skupine „štedljivih”, a jedan iz skupine „deklarativnih”.
Segmentation of the Inhabitants of Ljubljana with Regard to Environmental Issues

Segmentacija stanovnika

Ljubljane s obzirom na njihov odnos prema okolišu 
Tab. 3 Willingness actively to participate in the Healthy Drinking Water Foundation and the Ecological group and to join the Ecological group by extracted groups based on personal interviews

Tab. 3. Spremnost na aktivno sudjelovanje u Fondaciji za zdravu pitku vodu i skupini Ekologičen i za pridruženje skupini Ekologičen prema pojedinim skupinama

\begin{tabular}{|c|c|c|c|c|c|c|c|}
\hline Variable / Varijabla & $\begin{array}{c}\text { Unit / } \\
\text { Jedinica }\end{array}$ & 1 & 2 & 3 & 4 & 5 & 6 \\
\hline \multirow{2}{*}{$\begin{array}{l}\text { Willingness to contribute a monthly } \\
\text { amount of EUR } 0.5 \text { to the Healthy Drinking } \\
\text { Water Foundation / Spremnost na davanje } \\
\text { mjesečnog doprinosa od } 0,5 \text { eura Fondaciji za } \\
\text { zdravu pitku vodu }\end{array}$} & $\overline{\mathrm{x}}$ & 1.00 & 0.51 & 0.90 & 0.55 & 0.12 & 0.68 \\
\hline & Index & 147 & 75 & 132 & 81 & 17 & 100 \\
\hline \multirow{2}{*}{$\begin{array}{l}\text { Willingness to contribute a monthly amount } \\
\text { of EUR } 2 \text { or more to the Healthy Drinking } \\
\text { Water Foundation / Spremnost na davanje } \\
\text { mjesečnog doprinosa od } 2 \text { eura ili više Fon- } \\
\text { daciji za zdravu pitku vodu }\end{array}$} & $\overline{\mathrm{x}}$ & 0.40 & 0.05 & 0.26 & 0.1 & 0.04 & 0.19 \\
\hline & Index & 211 & 26 & 137 & 52 & 21 & 100 \\
\hline \multirow{2}{*}{$\begin{array}{l}\text { Willingness to join the Ecological group } \\
\text { / Spremnost na pridruživanje skupini } \\
\text { Ekologičen }\end{array}$} & $\overline{\mathrm{x}}$ & 0.53 & 0.18 & 0.10 & 0 & 0 & 0.18 \\
\hline & Index & 294 & 100 & 55 & 0 & 0 & 100 \\
\hline \multirow{2}{*}{$\begin{array}{l}\text { Number of respondents actually joining the } \\
\text { Ecological group / Broj ispitanika koji su se } \\
\text { stvarno pridružili skupini Ekologičen }\end{array}$} & $\overline{\mathrm{x}}$ & 0.18 & 0.04 & 0 & 0 & 0 & 0.04 \\
\hline & Index & 450 & 100 & 0 & 0 & 0 & 100 \\
\hline
\end{tabular}

(1 - active / aktivni, 2 - thrifty / štedljiji, 3 - in word only / deklarativni, 4 - passive / pasivni, 5 - indifferent / ravnodušni, 6- total / ukupno)

The share of women in the "active" group is above the average. Members of the group are predominantly between 25 and 44 years of age. As regards education, the group's share of respondents with short-term high, higher and university education is distinctly above the average, while in terms of income, members with above-average income predominate. The "thrifty" group also has an above-average share of women, while predominant age groups within the group are 45-64 and 65 or older. As regards the level of education, the "thrifty" group is characterised by lower education, with an above-average share of respondents with completed vocational and primary education. In terms of income, the "thrifty" group is mostly composed of respondents with the lowest income. In the "in word only" group, the share of men is above the average, while as regards age structure, there is an above-average share of respondents aged between 15 and 24 years, and between 45 and 64 years. Interestingly, in relation to the level of education, the group has an above-average share of respondents with completed secondary education, although it needs to be pointed out that the share of
Udio žena u skupini „aktivnih” prelazi prosjek. Većina je njezinih pripadnika u dobnoj skupini 25 - 44 godine. U pogledu obrazovanja udio ispitanika u skupini s višim, visokim i fakultetskim obrazovanjem izrazito je iznad prosjeka, dok po prihodima prevladavaju pripadnici s iznadprosječnim prihodima. U skupini „štedljivih” udio žena također prelazi prosjek, a u dobnoj strukturi prevladavaju pripadnici iz skupina $45-64$ i 65 i više godina. U pogledu obrazovanja skupinu „štedljivih” karakterizira niža razina obrazovanja s većim udjelom ispitanika sa završenim strukovnim i osnovnim obrazovanjem. Prema prihodima, u skupini „štedljivih” prevladavaju ispitanici s najnižim prihodima. U skupini „deklarativnih" udio je muškaraca iznad prosjeka, a u dobnoj strukturi iznad prosjeka je udio ispitanika iz dobnih skupina 15 - 24 i 45 - 64 godine. Zanimljivo, u pogledu obrazovanja u toj je skupini iznad prosjeka udio ispitanika sa završenim srednjim obrazovanjem, iako moramo istaknuti da je udio ispitanika sa završenim najvišim stup- 
respondents with the highest level of education is also considerable. Duality is also present as regards income: on the one hand, the group includes respondents with average or slightly below-average income per household, while on the other hand, it also includes a more than insignificant share of respondents with the highest income, i.e. EUR 3,000 or more per month per household. In the "passive" group, both sexes are fairly equally represented, which can also be observed in the age structure - all age groups are represented rather equally. As regards education structure, the group is characterised by the above-average share of respondents with lower education. As for income, the "passive" group is predominantly composed of respondents with below-average income. In the so-called "indifferent" group, there is an above-average share of men between 45 and 64 years of age. As regards education level, there is an above-average share of respondents with lower education, predominantly with vocational and primary education. Another characteristic of this group is that the income of its members is below the average, but interestingly enough, not the lowest.

\section{Conclusion}

Although it seems that people living within a particular environment nowadays have similar lifestyles, it was found that they are not a homogenous group with regard to their level of environmental awareness and engaging in environmental behaviour. As a group, they cannot be easily identified and described, since significant differences exist among the respondents. They were successfully divided into five distinctive groups.

Based on the results of arranging the respondents into groups and the results of measuring specific behavioural dimensions, it has been established that the "active" group can be placed the highest on the scale as regards their environmental awareness, while their actions testify that they also actually engage in environmental behaviour in practice. At the declarative, as well as operational level, they are characterised by the above-average trend of positive answers, the distinctly above-average level of knowledge and the actions themselves. Nevertheless, individuals who can be characterised as "environmental activists" can be identified within the so-called "environmental body". Namely, by actually joining the Ecological group and their ac- njem obrazovanja također znatan. Dvostrukost je prisutna i u pogledu prihoda: s jedne strane, skupina uključuje ispitanike s prosječnim ili malo ispodprosječnim prihodima po kućanstvu, dok s druge uključuje i ne toliko beznačajan udio ispitanika s najvišim prihodima, tj. 3000 ili više eura po kućanstvu. U skupini „pasivnih” oba su spola podjednako zastupljena, a isto je bilo utvrđeno i za dobnu strukturu - sve su dobne skupine zastupljene prilično podjednako. Prema strukturi obrazovanja, skupinu karakterizira iznadprosječni udio ispitanika s nižom razinom obrazovanja. U pogledu prihoda skupina „pasivnih” pretežno uključuje ispitanike s ispodprosječnim prihodima. U skupini „ravnodušnih” udio muškaraca iz dobne skupine $45-64$ godine prelazi prosjek. $U$ pogledu obrazovanja udio je ispitanika s nižom razinom obrazovanja iznad prosjeka, pretežno sa završenim strukovnim i osnovnim obrazovanjem. Za tu je skupinu također karakteristično da su prihodi njenih pripadnika ispod prosjeka ali, zanimljivo, ne i najniži.

\section{Zaključak}

Iako se čini da ljudi koji danas žive u određenoj sredini imaju slične životne stilove, utvrđeno je da nije riječ o homogenoj skupini u pogledu njihove razine ekološke svijesti i primjene okolišno pogodnog ponašanja. Kao skupina oni se ne mogu lako prepoznati ni opisati jer postoje znatne razlike među ispitanicima. Identificirano je pet prepoznatljivih skupina ispitanika.

$\mathrm{Na}$ osnovi grupiranja ispitanika u skupine i rezultata mjerenja specifičnih dimenzija koje se odnose na ponašanje utvrđeno je da se skupinu „aktivnih" može smjestiti na vrh ljestvice u pogledu njihove ekološke svijesti, dok njihovo djelovanje svjedoči da oni također aktivno primjenjuju okolišno pogodno ponašanje u praksi. $\mathrm{Na}$ deklarativnoj kao i operativnoj razini njih karakteriziraju iznadprosječni trend pozitivnih odgovora te izrazito iznadprosječna razina znanja, a i samog djelovanja. No unutar takozvanog „ekološkog tijela" mogu se izdvojiti pojedinci koje možemo nazvati „ekološkim aktivistima”. Naime stvarnim pridruženjem skupini Ekologičen i aktivnim su-
Segmentation of the Inhabitants of Ljubljana with Regard to Environmental Issues

Segmentacija stanovnika

Ljubljane s obzirom na njihov odnos prema okolišu 
GEOGRAFSKI

GLASNIK

78/1, 25-44 (2016.) tive engagement in it, they demonstrated their desire for taking more serious, organised action. Within the entire studied population, one out of every 25 respondents (4.2\%) can be characterised as an "environmental activist", which is roughly in line with the results of the Slovenian Public Opinion Pool 2011 (Toš, 2012), where the share of respondents who were members of any of the groups primarily aimed at preservation and protection of the environment was 3.6\%. The "thrifty" group, at the declarative level, are convinced that the environment needs to be protected, but they can also be characterised as sceptics, since they are predominantly convinced that they cannot significantly contribute to environmental protection, particularly if it is not practiced by others. However, on the other hand, their past actions show that they nevertheless do engage in environmental behaviour; however, the basic reason behind their engagement is to save financial resources, not to protect the environment. Namely, the results show rather below-average willingness to contribute to the Foundation, in particular where the amount of contribution is EUR 2 or more, combined with an above-average willingness to join and actual joining the Ecological group. Furthermore, the above findings are confirmed by the characteristics of values, since the "thrifty" respondents assign above-average importance to egoistic values, while they attribute below-average importance to biospheric values. The reason behind such a distinct importance assigned to financial resources by this group is their income and last, but not least, their education level. The "in word only" group is characterised by the distinct duality between their verbally expressed environmental awareness and actual behaviour. At the declarative level, members of the group rated the importance of environmental protection even higher than members of the "active" group, but when they are faced with limitations brought along by actual environmental activity, their zeal dissipates rapidly. On the one hand, they demonstrate above-average willingness to contribute to the Healthy Drinking Water Foundation in the amount of EUR 0.5, while on the other their willingness to join the Ecological group and give their e-mail address is distinctly below the average. It is extremely interesting that the share of those willing to contribute EUR 2 or more for the Healthy Drinking Water Foundation is distinctly above the average. It indicates the need for a more detailed insight into data and an additional analysis of the group djelovanjem u njoj oni su iskazali želju za ozbiljnijim, organiziranijim djelovanjem. Unutar cjelokupne istražene populacije jedan od 25 ispitanika $(4,2 \%)$ može biti okarakteriziran kao „ekološki aktivist”, što je približno u skladu s rezultatima istraživanja Slovensko javno mišljenje (ur. Toš, 2012), po kojima je udio ispitanika učlanjenih u bilo koju skupinu s primarnim ciljem očuvanja ili zaštite okoliša bio 3,6 \%. Skupina „štedljivih” na deklarativnoj je razini uvjerena da okoliš treba štititi, no ona može biti okarakterizirana i kao skeptična jer ispitanici u toj skupini pretežno su uvjereni da ne mogu bitno pridonijeti zaštiti okoliša, osobito ako se o tome ne brinu i drugi. No, s druge strane, njihovo prethodno djelovanje pokazuje da ipak primjenjuju okolišno primjereno ponašanje, iako je njegova glavna svrha uštedjeti novac, a ne očuvati okoliš. Naime rezultati pokazuju ispodprosječnu spremnost za davanje doprinosa Fondaciji, osobito kada je posrijedi iznos od dva ili više eura, dok istovremeno spremnost na pridruženje skupini Ekologičen prelazi prosjek. Te zaključke potvrđuju i karakteristike vrijednosti jer ispitanici iz skupine „štedljivih” pripisuju iznadprosječno značenje egoističnim vrijednostima, dok biosferskim vrijednostima pripisuju ispodprosječno značenje. Pripadnici te skupine pripisuju toliko izrazito značenje financijskim resursima zbog svojih prihoda, a tome nemalo pridonosi i razina njihova obrazovanja. Skupinu „deklarativnih” karakterizira izrazita oprečnost između verbalno izražene ekološke svijesti i stvarnog ponašanja. $\mathrm{Na}$ deklarativnoj su razini pripadnici te skupine zaštiti okoliša pripisali čak i veće značenje nego pripadnici skupine „aktivnih”, no kada su suočeni s ograničenjima ekološkog djelovanja, njihovo oduševljenje naglo splasne. S jedne strane, oni pokazuju iznadprosječnu spremnost na doprinos Fondaciji za zdravu pitku vodu u iznosu od 0,5 eura, dok je s druge strane njihova spremnost da se uključe u skupinu Ekologičen i daju svoju adresu elektroničke pošte izrazito ispod prosjeka. Iznimno je zanimljivo da je izrazito iznadprosječan udio onih koji su spremni dati dva ili više eura Fondaciji za zdravu pitku vodu. To pokazuje da su potrebni detaljniji uvid u podatke i dodatna analiza te skupine. Detaljnija analiza odgovora onih koji su spremni dati dva ili više 
with which we are dealing. The more detailed analysis of answers given by those who are willing to contribute EUR 2 or more for the Healthy Drinking Water Foundation reveals that a subgroup named "selfish" can be formed within the "in word only" group, consisting of less than a tenth (8.5\%) of all respondents and slightly less than a third (32.4\%) of members of the "in word only" group. The subgroup consists of individuals who are well aware of the importance of environmental protection and fully support such behaviour at the declarative level. They also have above-average knowledge about the relevant behaviour and are actually willing to contribute considerably for the benefit of the environment, but only financially. They are also willing to contribute considerably more than merely a minimal or average amount for environmental protection purposes, but when faced with actual activity, their eagerness takes an entirely opposite direction. Namely, none of the members of this subgroup is willing to join the Ecological group and in this way contribute to environmental protection. The demographic analysis of the subgroup reveals that it is comprised predominantly of men with an above-average education level and an income that is considerably above the average. Let us mention the statement or comment given by one of the "selfish" subgroup members who snapped at the interviewer: "I pay you 2 EUR or possibly even more, but then you leave me alone". This statement indicates quite well with which subgroup of people we are dealing. Further on, the "passive" group is also characterised by duality or disparity between declarative and actual behaviour, with the distinction that they are even more passive. While they demonstrate a rather high level of concern about the environment, their real attitude is revealed by the level of motivation for environmental protection, which is considerably below the average, their lack of knowledge and particularly by their lack of concrete active engagement. The "indifferent" group can be described in other words as apathetic, not assigning any importance to environmental protection, which they demonstrate by behaving in such a way. Thus, they demonstrate complete reluctance to participate and they actually stand behind their attitudes.

Apart from the above-described findings, the research provides interesting starting points for future research. It was established that although people are generally quite willing to engage in environmental behaviour as a matter of principle, not many are truly eura Fondaciji za zdravu pitku vodu pokazuje da unutar skupine „deklarativnih” možemo formirati podskupinu „sebični”, koja obuhvaća manje od desetine $(8,5 \%)$ svih ispitanika ili malo manje od trećine $(32,4 \%)$ pripadnika skupine "deklarativnih". Podskupina se sastoji od pojedinaca koji su svjesni značenja zaštite okoliša i potpuno podupiru takvo ponašanje na deklarativnoj razini. Njihovo je poznavanje odgovarajućeg ponašanja iznadprosječno i doista su spremni značajno pridonijeti dobrobiti okoliša, ali isključivo u financijskom smislu. Također su spremni znatno više od minimalnog iznosa pridonijeti zaštiti okoliša, dok su u pogledu spremnosti na aktivno sudjelovanje njihovi stavovi potpuno suprotni. Naime nijedan pripadnik te podskupine ne želi se učlaniti u skupinu Ekologičen i na taj način pridonijeti zaštiti okoliša. Demografska analiza podskupine pokazuje da obuhvaća pretežno muškarce s iznadprosječnom razinom obrazovanja i prihodima koji su znatno iznad prosjeka. Možemo spomenuti izjavu ili komentar jednog pripadnika podskupine „sebičnih” koji je anketaru odbrusio: „Platit ću vam dva eura, a možda i više, ali nakon toga me ostavite na miru." Ta izjava prilično dobro pokazuje o kakvim je ljudima riječ. Nadalje, skupinu „pasivnih” također karakterizira nesklad između deklarativnog i stvarnog ponašanja, s tom razlikom da su oni čak i pasivniji. Dok pokazuju relativno visoku razinu brige za okoliš, njihov je pravi odnos razotkriven razinom motiviranosti za zaštitu okoliša, koja je značajno ispod prosjeka, njihovim nedostatnim znanjem i osobito nedostatkom konkretnoga aktivnog djelovanja. Skupinu „ravnodušnih” možemo drugim riječima opisati kao nezainteresiranu skupinu kojoj zaštita okoliša ne znači ništa i koja se tako i ponaša. Tako pokazuju potpunu nesklonost sudjelovanju i doista stoje iza svog stava.

Osim gore opisanih nalaza ovo istraživanje daje zanimljiva polazišta za buduća istraživanja. Utvrđeno je da iako su se ljudi u načelu općenito prilično spremni ekološki ponašati, malo je takvih koji su i u praksi stvarno spremni djelovati u korist okoliša. S druge strane, pozitivna je činjenica da su rijetki ljudi koje zaštita okoliša nimalo ne zanima; velika većina može se smjestiti negdje između te dvije krajnosti. Njihova je zajednič-
Segmentation of the Inhabitants of Ljubljana with Regard to Environmental Issues

Segmentacija stanovnika

Ljubljane s obzirom na njihov odnos prema okolišu 
GEOGRAFSKI

GLASNIK

78/1,25-44 (2016.) willing to do something for the environment when it comes to action. On the other hand, there is the positive fact that not many people have absolutely no interest in environmental protection; the vast majority can be placed somewhere in-between. Their common characteristic is that they highly support environmental protection and are rather familiar with the ways of addressing environmental protection issues, but do not actually engage in such behaviour. They have an alienated attitude towards the environment and often find themselves caught in the clutch of other non-environmental priorities. On the other hand, however, these respondents are the most interesting from the perspective of being capable of changing their actual behaviour because they are most susceptible to behavioural changes, given the appropriate use of strategies. Besides, they represent a large or the largest share of the entire population. On the other hand, the environmentally most active, in other words the sworn environmentalists, are considerably less interesting for researchers, because in this case it is about convincing the convinced, which is rather pointless and, besides, their share in the population is not high. A less interesting group are also those who are the least interested in the environment because a lot of effort needs to be put into those groups. Namely, they have absolutely no interest in changing their behaviour and are not prepared to change.

Therefore, dividing people into groups while carefully planning relevant strategies that will prepare the environmentally aware but passive to actually start engaging in relevant behaviours, is of crucial importance. Namely, good understanding and high awareness that also lead to relevant shifts in practice can only be achieved by the use of well-selected and adapted strategies (which should be adapted to characteristics of specific groups and based on a practical approach) for building environmental awareness and changing behaviour.

Note Napomena
Professional Terms Editing: Martina Jakovčić, $\mathrm{PhD}$, Assistant Professor ka osobina da snažno podupiru zaštitu okoliša i da im je prilično dobro poznato što bi trebali činiti za očuvanje okoliša, ali se tako ne ponašaju. Njihov je odnos prema okolišu otuđen i često se nađu u vlastitom žrvnju za okoliš nepogodnih prioriteta. S druge strane, ti su ispitanici najzanimljiviji po tome što su sposobni promijeniti stvarno ponašanje jer su najskloniji promjenama ponašanja uz primjerenu upotrebu strategija. Osim toga oni predstavljaju veliki ili najveći udio cjelokupne populacije. S druge strane, za istraživače su znatno nezanimljiviji ekološki najaktivniji ili, drugim riječima, oni koji se aktivno zalažu za očuvanje okoliša, jer u tom slučaju riječ je o uvjeravanju uvjerenih, što je prilično besmisleno, a usto njihov udio u populaciji nije velik. Manje su zanimljiva skupina i oni koje okoliš najmanje zanima jer bi u tu skupinu trebalo uložiti puno truda. Naime oni nemaju apsolutno nikakvog interesa za promjenu svog ponašanja i nisu se spremni promijeniti.

Stoga je ključno svrstavanje ljudi u skupine uz pomno planiranje relevantnih strategija koje će pripremiti ekološki svjesne, ali pasivne da počnu primjenjivati prihvatljivo ponašanje. Naime dobro razumijevanje i visoka razina svijesti koji vode $\mathrm{i}$ do prihvatljivih promjena u praksi mogu se postići samo primjenom dobro odabranih i prilagođenih strategija (koje bi trebale biti prilagođene osobinama pojedinačnih skupina i koje bi se trebale temeljiti na praktičnom pristupu) za razvoj ekološke svijesti i postizanje promjena $u$ ponašanju.

Stručna redaktura: Doc. dr. sc. Martina Jakovčić 
Abrahamse, W., 2007: Energy conservation through behavioral change: Examining the effectiveness of a tailor-made approach, Unpublished doctoral thesis, University of Groningen, Groningen.

Ajzen, I., 1991: The theory of planned behaviour, Organizational Behaviour and $\mathrm{Hu}$ man Decision Processes 50 (2), 179-211.

Ajzen, I., 2015: The theory of planned behaviour is alive and well, and not ready to retire: a commentary on Sniehotta, Presseau, and Araújo-Soares, Health Psychology Review 9 (2), 131-137.

Ajzen, I., Klobas, J., 2013: Fertility intentions: An approach based on the theory of planned behaviour, Demographic Research 29 (8), 203-232.

Bamberg, S., Schmidt, S. 2003: Incentives, Morality, Or Habit? Predicting Students' Car Use for University Routes With the Models of Ajzen, Schwartz, and Triandis, Environment and Behaviour 35 (2), 264-285.

Bonini, S., Oppenheim, J., 2008: Cultivating the Green Consumer, Stanford Social Innovation Review 6 (4), 56-61.

Clark, C. F., Kotchen, M. J., Moore, M. R., 2003: Internal and external influences on pro-environmental behavior: Participation in a green electricity program, Journal of Environmental Psychology 23, 237-246.

Conner, M., Armitage, C. J. 1998: Extending the Theory of Planned Behaviour: A Review and Avenues for Further Research, Journal of Applied Social Psychology 28 (15), 1429-1464.

Cronbach L. J., 1951: Coefficient alpha and the internal structure of tests, Psychometrika 16 (3), 297-334.
Culiberg, B., Rojšek, I., 2007: Who cares? - segmentation of environmentally conscious consumers, in: Values and economy (eds. Polič, M., Bajec, B., Komidar, L.), Faculty of Arts, Ljubljana, 63-70.

De Groot, J. I. M., Steg, L., 2007: Value Orientations and Environmental Beliefs in Five Countries: Validity of an Instrument to Measure Egoistic, Altruistic and Biospheric Value Orientations, Journal of Cross-Cultural Psychology 38 (3), 318-332.

D'Souza, C., Taghian, M., Lamb, P., 2006: An empirical study on the influence of environmental labels on consumers, Corporate Communications: An International Journal 11 (2), 162-173.

Fraj, E., Martinez, E., 2006: Environmental values and lifestyles as determining factors of ecological comsumer behaviour: an empirical analysis, Journal of Consumer Marketing 23 (3), 133-144.

Gifford, R., Nilsson, A., 2014: Personal and social factors that influence pro-environmental concern and behaviour: A review, International Journal of Psychology 49 (3), 141-157.

Gilg, A., Barr, S., Ford, N., 2005: Green consumption or sustainable lifestyles? Identifying the sustainable consumer, Futures 37 (6), 481-504.

Ginsberg, J. M., Bloom, P. N., 2004: Choosing the right green marketing strategy, MIT Sloan Management Review 46 (1), 79-84.

Ham, M., 2009: Consumer segmentation based on the level of environmental responsibility, Tržište 21 (2), 183-202.

Harland, P., Staats, H., Wilke, H. A., M., 1999: Explaining Proenvironmental Intention and Behaviour by Personal
Norms and the Theory of Planned Behaviour, Journal of Applied Social Psychology 29 (12), 2505-2528.

Heath, Y., Gifford, R., 2002: Extending the theory of planned behaviour: Predicting the use of public transportation, Jounal of Applied Social Psychology 32, 21542189

Kaiser, F. G., 2006: A moral extension of the theory of planned behaviour: Norms and anticipated feelings of regret in conservationism, Personality and Individual Differences 41 (1), 71-81.

Kollmuss, A., Agyeman, J., 2002: Mind the Gap: why do people act environmentally and what are the barriers to pro-environmental behavior?, Environmental Education Research 8 (3), 239-260.

Lehman, P. K., Geller, E. S., 2004: Behaviour analysis and environmental protection: Accomplishments and potential for more, $B e-$ haviour and Social Issues 13 (1), 13-33.

Nordlund, A. M., Garvill, J. 2002: Value Structures behind Proenvironmental Behaviour, Environment and Behaviour 34 (6), 740-756.

Plut, D., 2014: Ekosocializem ali barbarstvo: demokratični ekološki socializem in trajnostni sonaravni razvoj, Društvo gibanje za trajnostni razvo Slovenije, Ljubljana.

Polajnar, K., 2008: Public awareness of wetlands and their conservation, Acta geographica Slovenica 48 (1), 121-146.

Polajnar Horvat, K., 2012: Oblikovanje modela razvoja okoljske ozaveščenosti in okolju prijaznega vedenja, Geografski vestnik 84 (2), 43-52.

Polajnar Horvat, K., 2014: Vloga socialnih dejavnikov pri razvoju okoljske ozaveščenosti in spreminjanju okoljskega vedenja, Unpublished Doctoral dissertation, University of Ljubljana. Ljubljana.

Schultz, P. W., Zelezny, L. C., 1999: Values as predictors of environmental attitudes: Evidence for consistency across 14 countries, Journal of Environmental psychology 19 (3), 255-265.

Schwartz, S. H., 1992: Universals in the content and structure of values: Theoretic advances and empirical tests in 20 countries, in: Advances in Experimental Social Psychology 25 (ed. Zanna, M. P.), Academic Press, San Diego, 1-65.

Smrekar, A., 2011: From environmental awareness in word to environmental awareness in deed: The case of Ljubljana, Acta geographica Slovenica 51 (2), 277-292.

Smrekar, A., 2012: Environmental awareness in Slovenia through residents' relationship to waste, Geografski vestnik 84 (1), 129-139.

Steg, L., Perlaviciute, G., van den Verff, E., Lurvink, J., 2012: The Significance of Hedonic Values for Environmentally Relevant Attitudes, Preferences, and Actions, Environment and Behaviour 1 (30), 1-30.

Steg, L., Nordlund, A., 2013: Models to explain environmental behaviour, in: Environmental Psychology (eds. Steg, L., Van Den Berg, A. E., De Groot, J. I. M.), BPS Blackwell, West Sussex, 185-195.

Stern, P. C., Dietz, T., Abel, T., Guagnano, G. A., Kalof, L., 1999: A Value-Belief-Norm Theory of Support for Social Movements: The Case of Environmentalism, Human Ecology Review 6, 81-97.

Stern, P. C., 2000: Toward a Coherent Theory of Environmentally Sigificant Behaviour, Journal of Social Issues 56 (3), 407-424.
Segmentation of the Inhabitants of Ljubljana with Regard to

Environmental Issues

Segmentacija stanovnika

Ljubljane s obzirom na njihov odnos prema okolišu

\section{Literature} Literatura 
HRVATSKI

GEOGRAFSKI

GLASNIK

78/1, 25-44 (2016.)
Stern, P. C., Dietz, T., 1994: The Value Ba- Toš, N. (ed.), 2012: Vrednote v prehodu VII: sis of Environmental Concern, Journal of Slovenija v mednarodnih in medialovnih Social Issues 50 (3), 65-84. primerjavah SJM - ISSP 1991-2012,
Edition Echoraum, University of Ljubljana, Wien, Ljubljana. 